\title{
3. Formal recognition of adult relationships and legal gender in a comparative perspective
}

\author{
Jens M. Scherpe
}

\section{IN THE BEGINNING THERE WAS MARRIAGE . . .}

Until fairly recently, family law was solely focused on marriage, understood as the union of a man and a woman for life. ${ }^{1}$ Indeed, families were only created through and by that kind of marriage, and any adult relationship beyond that was not even deemed to be family. ${ }^{2}$ Thus, relationship recognition was by default gendered.

At the beginning of the twenty-first century, families and recognised familial relationships beyond opposite sex marriage existed in many jurisdictions. ${ }^{3}$ Particularly after the Second World War, and as a reaction to the atrocities of that war, there was a much greater focus on human rights - strengthening individual and private autonomy, as well as the respect for private life/privacy. ${ }^{4}$ In addition, for many reasons, societies changed and became more liberal

1 For England and Wales, the 'classic' definition was that spelled out in the case of Hyde v Hyde and Woodmansee [1866] LR 1 P \& D 130 (20 March 1866): 'I conceive that marriage, as understood in Christendom, may for this purpose be defined as the voluntary union for life of one man and one woman, to the exclusion of all others.' On this case see Rebecca Probert, 'Hyde v Hyde: Defining or Defending Marriage?' (2007) 19 Child and Family Law Quarterly 322-36.

2 See for example the English decision of Gammans v Ekins [1950] 2 KB 328 ('To say of two people masquerading, as these two were, as husband and wife - there being no children to complicate the picture - that they were members of the same family, seems to me an abuse of the English language', per Asquith LJ), followed by Ross v Collins [1964] 1 WLR 425. But cf the change in attitude expressed by Lord Denning MR in Dyson Holdings Ltd. v Fox [1976] QB 503, leading to the finding that Gammans was wrongly decided.

3 For seminal texts on these developments see John Eekelaar, Family Law and Social Policy (Weidenfeld \& Nicholson 1978); John Eekelaar, 'Family Law and Social Control' in John Eekelaar and John Bell (eds), Oxford Essays in Jurisprudence, 3rd Series (Oxford University Press 1987); John Eekelaar, Family Law and Personal Life (Oxford University Press 2006; paperback version 2007 with additional chapter); Katherine O'Donovan, Family Law Matters (Pluto Press 1993); Richard Collier, Masculinity, Law and the Family (Routledge 1995); John Dewar, 'The Normal Chaos of Family Law' (1988) 61 Modern Law Review 467-85; Ulrich Beck and Elizabeth Beck-Gernsheim, The Normal Chaos of Love (3rd edn, Polity 1995); Gillian Douglas, Obligation and Commitment in Family Law (Hart Publishing 2018). For historical perspectives see Stephen Cretney, Family Law in the Twentieth Century - A History (Oxford University Press 2003); Rebecca Probert, The Changing Legal Regulation of Cohabitation - From Fornicators to Family 1600-2010 (Cambridge University Press 2015); Rebecca Probert, Marriage Law and Practice in the Long Eighteenth Century: A Reassessment (Cambridge University Press 2009); Masha Antokolskaia, Harmonisation of Family Law: A Historical Perspective (Intersentia 2006).

4 See for example the impact of Marckx $v$ Belgium [1979] ECHR 2 (13 June 1979), which established that children are to be treated equally, irrespective of whether they were born in or out of wedlock. On this case and its importance for European family law see Walter Pintens and Jens M Scherpe, 'The Marckx Case: A "Whole Code of Family Law"?' in Stephen Gilmore, Jonathan Herring and Rebecca 
with regard to relationships. As a result, the dominance of marriage as the only acceptable family form was increasingly challenged, ${ }^{5}$ as were the conceptions underlying that legal and social institution. ${ }^{6}$ The (increasingly openly) lived realities of many couples of the same or the opposite sex simply were no longer reflected by the law. ${ }^{7}$ Denying these couples, who often functioned in very similar ways to married couples, legal recognition simply became less and less acceptable to societies. As Ward LJ put it in the English Court of Appeal decision in Fitzpatrick $v$ Sterling Housing Association Ltd: "the question is more what a family does than what a family is. A family unit is a social organisation which functions through its linking of members closely together. The functions may be procreative, sexual, sociable, economic, emotional.' $^{8}$

Across Europe and beyond, there was a move towards a functional definition of family, and thus recognition of adult relationships beyond marriage without requiring the couple to be of the opposite legal gender. Much of the discussion was dominated by two topics, namely the need to provide legal recognition, and thus a legal framework, for (a) same sex couples and (b) unmarried couples (either generally or restricted to couples of the opposite sex). Given the remit of this volume, the focus of this contribution will be on the former rather than the latter

Probert (eds), Landmark Cases in Family Law (Hart Publishing, 2011; paperback edition 2016) 155-74; Walter Pintens and Jens M Scherpe, 'Die Marckx-Entscheidung des Europäischen Menschengerichtshofs als Keimzelle eines europäischen Familien- und Erbrechts. Ein Rück- und Ausblick nach fünfunddreißig Jahren' in Normann Witzleb, Reinhard Ellger, Peter Mankowski, Hanno Merkt and Oliver Remien (eds), Festschrift für Dieter Martiny zum 70. Geburtstag (Mohr Siebeck 2014) 127-46; Jens M Scherpe, The Present and Future of European Family Law (Edward Elgar 2016), esp 7-11. Another example is Schalk and Kopf v Austria, [2010] ECHR 995, in which a same sex couple was (finally) recognised to have 'family life' (on this see for example Jens M Scherpe, 'From "Odious Crime" to Family Life - Same-Sex Couples and the ECHR' in Alain-Laurent Verbeke, Jens M Scherpe, Charlotte Declerck, Tobias Helms and Patrick Senaeve (eds), Confronting the Frontiers of Family and Succession Law - Liber amicorum Walter Pintens (Intersentia 2012) 1225-40; Jens M Scherpe, 'The Legal Recognition of Same-Sex Couples in Europe and the Role of the European Court of Human Rights' (2013) 10 The Equal Rights Review, 83-96, available in print and at www.equalrightstrust.org/ertdocumentbank/ERR10_sp1.pdf, accessed 23 April 2017).

5 Or, as Harry Krause has put it, 'the sole legally and morally permissible harbour for sexual activity and child-rearing': in Chapter 34, 'Comparative Family Law' in Mathias Reiman and Reinhard Zimmermann (eds), The Oxford Handbook of Comparative Law (Oxford University Press 2006).

6 See for example Eric Clive, 'Marriage: An Unnecessary Legal Concept?' in John Eekelaar and Sanford Katz (eds), Marriage and Cohabitation in Contemporary Societies (Butterworths 1981) 71-81; Caroline Sörgjerd, 'Marriage in a European Perspective' in Jens M Scherpe (ed.), European Family Law Vol. III - Family Law in a European Perspective (Edward Elgar 2016) 3-40; Caroline Sörgjerd, Reconstructing Marriage: The Legal Status of Relationships in a Changing Society (Intersentia 2012).

7 I am using the terms same sex/opposite sex throughout this contribution instead of, as is sometimes done, homosexual/heterosexual. The latter terms would be misleading in the context of relationship recognition, as there are/were no legal requirements regarding sexual orientation (with the possible exception of Norway: see Thomas Eeg, 'Registered Partnerships in Norway' in Jens M Scherpe and Andy Hayward (eds), The Future of Registered Partnerships - Family Recognition Beyond Marriage? (Intersentia 2017) 43-69) but merely requirements regarding the legal gender of the persons.

8 [1998] Ch 304, 339; the legal question in the case was whether the longterm relationship between two men could be classified as 'family' for the purposes of the Rent Act 1977. Interestingly, the Court of Appeal felt unable to 'change the law' on this point, stating that this was a matter for Parliament. The House of Lords later had no such difficulties (although admittedly only by a very small majority): [1999] UKHL 42. 
(see sections 2 and 3 of this chapter), ${ }^{9}$ although of course the topics overlap. However, it is important to note that current legal challenges go even further, questioning whether recognition of a relationship should be based on conjugality/coupledom or restricted to two persons (on which see section 5 of this chapter) and even the concept of legal gender itself (on which see section 3.3 of this chapter).

\section{THERE IS FAMILY OUTSIDE MARRIAGE: REGISTERED PARTNERSHIPS}

\subsection{Same Sex Couples as 'A Perfectly Acceptable Form of Family Life'}

While there have of course always been familial relationships outside of 'traditional' marriage, it was the greater societal acceptance of such relationships in the second half of the twentieth century that made them more visible and allowed the legal issues surrounding them to come to the fore. Cohabitation became (and indeed continues to become) more common, and same sex couples gradually became first tolerated and then accepted. Unsurprisingly, the Nordic Countries took the lead in this, with the Swedish lagutskottet (committee on legal affairs) in 1973 being the first to expressly state that 'from society's point of view, two persons of the same sex living together as a couple was a perfectly acceptable form of family life' ${ }^{10}$ From 1977 on, a commission then looked into creating a legal framework for same sex couples to formalise their relationships, but in its 1984 report it concluded that it would be preferable to extend legal rules for opposite sex cohabitants, ${ }^{11}$ which were already in existence, to same sex cohabitants. ${ }^{12}$ Nevertheless, Sweden thus became the first country in the world to incorporate same sex couples into the family law system - even if only to a very limited extent.

\subsection{The (More or Less) Functional Equivalents}

Denmark then took things further. In May 1984, the Danish Parliament (folketing) passed a resolution that homosexual men and women must be given the possibility to live openly in society. As a result, a commission was formed to look into proposals for ending any form of

9 For a comparative discussion of the regulation of cohabitation see Joanna Miles, 'Unmarried Cohabitation in a European Perspective' in Jens M Scherpe (ed), European Family Law Vol. III - Family Law in a European Perspective (Edward Elgar 2016) 82-115; Jens M Scherpe and Nadjma Yassari (eds), Die Rechtsstellung nichtehelicher Lebensgemeinschaften - The Legal Status of Cohabitants (Mohr Siebeck 2005); Inge Kroppenberg, Dieter Schwab, Dieter Henrich, Peter Gottwald and Andreas Spickhoff (eds), Rechtsregeln für nichteheliches Zusammenleben (Gieseking 2009).

10 Lagutskottes betänkande (LU) 1973:20 i anledning av Kungs Majt:ts proposition 1973:32 med förslag till lag om ändring i giftermålsbalken m.m., jämte motioner, 116.

11 Lag (1987:232) om sambors gemensamma hem.

12 Statens offentlige utredningar (SOU) 1984:63, Homosexuella och samhället. Betänkande av utrednuingen om homosexuellas situation I samhället, p.87 f. This was then enacted as lag (1987:813) om homosexuella sambor. For an overview of the development see Hans Ytterberg, "'From Society's Point of View, Cohabitation between Two Persons of the Same Sex is a Perfectly Acceptable Form of Family Life": A Swedish Story of Love and Legislation' in Robert Wintemute and Mads Andenæs (eds), Legal Recognition of Same-Sex Partnerships: A Study of National, European and International Law (Hart Publishing 2001) 430-6. 
discrimination, and also into possible regulation of stable, long term relationships of same sex couples. In 1988 the commission presented its report, ${ }^{13}$ which included a 'sketch' of an Act on registered partnerships for same sex couples. However, the commission voted against implementing such a proposal (by six votes to five), pointing out that the couples that needed this protection the most were the ones who would not opt into such a legal regime in any event. ${ }^{14}$ Remarkably, some Members of Parliament nevertheless decided to put forward a bill based on the sketch, ${ }^{15}$ without much explanation beyond a reference to the views of the minority of the commission. Somewhat surprisingly, Parliament voted in favour of the Bill by a large majority. ${ }^{16}$ Denmark became the first country in the world to allow same sex couples to formalise their relationship and acquire an officially recognised legal status for their relationship, acting as a trailblazer for future developments. ${ }^{17}$

The Danish registered partnership created a 'functional equivalent to marriage', ${ }^{18}$ extending most (but, at least not at first, not all) legal rules applying to marriage to registered partners. ${ }^{19}$ Many jurisdictions followed this approach, ${ }^{20}$ albeit often in somewhat technically more complicated ways. ${ }^{21}$ Others took an approach that was structurally similar (a legal regime exclusive to same sex couples), but with fewer legal rights and duties than those for marriage. ${ }^{22}$

\subsection{The 'Alternatives' to Marriage (For Some)}

However, several jurisdictions took a somewhat different approach and created a registered partnership regime that was open not only to same sex couples, but also to opposite sex couples. The idea behind this was that the ever increasing number of unmarried couples likewise required some form of legal framework. ${ }^{23}$ In hindsight, this approach was flawed from the

13 Betænkning 1127/1988; for an account of the appointment of the commission see ibid at 104.

14 Betænkning 1127/1988, 125.

15 Lovforslag No L 117 and 118 til Lov om registreret partnerskab (22.11.1988).

1671 for, 47 against, 5 abstentions. See Folketingets forhandlinger 1988-9, column 10840. Only members of the Christian-conservative parties seriously opposed the bill: see, for example, MPs Inger Stilling Pedersen (Kristeligt Folkeparti [KRF]), Folketingets forhandlinger 1988-89, columns. 10473 f., 10476, 10826 und 10834-6; Glønberg (KRF) ibid, column 10477 f.; Fischer (Konservative Folkeparti) ibid, column 10824 f.; Bjørn Elmquist (Venstre) ibid, column 10828 f., 10831; Kofod-Svendsen (KRF) ibid, column $10837 \mathrm{f}$.

17 On this see for example Jens M Scherpe, 'The Nordic Countries in the Vanguard of European Family Law' (2007) 50 Scandinavian Studies in Law 265-87, and Peter Dopffel and Jens M Scherpe, 'Gleichgeschlechtliche Lebensgemeinschaften im Recht der nordischen Länder' in Jürgen Basedow, Klaus Hopt, Hein Kötz and Peter Dopffel (eds), Die Rechtsstellung gleichgeschlechtlicher Lebensgemeinschaften (Mohr Siebeck 2000) 7-49.

18 In this context this term was coined by H Kötz, P Dopffel and JM Scherpe, 'Rechtsvergleichende Gesamtwürdigung und Empfehlungen' in Jürgen Basedow, Klaus Hopt, Hein Kötz and Peter Dopffel (eds), Die Rechtsstellung gleichgeschlechtlicher Lebensgemeinschaften (Mohr Siebeck 2000) 391-423.

19 See Dopffel and Scherpe above, n 17.

20 For example Norway (1993), Sweden (1994), Iceland (1996) and Finland (2001).

21 For example, for political reasons, Germany (2001) and the United Kingdom (2004) chose to create separate statutory frameworks containing every single provision that was to apply instead of the technically much simpler - general reference to the law of marriage.

22 For example, Slovenia (2006), the Czech Republic (2006), Switzerland (2007), Austria (2010) and Ireland (2011).

23 Cf the data presented in Anne Barlow, Simon Duncan, Grace James and Alison Park, Cohabitation, Marriage and the Law: Social Change and Legal Reform in the 21st Century (Hart Publishing 2005) 
beginning, for two reasons. First, it created an alternative to marriage for opposite sex couples, but at the same time was the only option for same sex couples to formalise their relationships. This obviously created a hierarchy and inequality, as the former could choose between two regimes to formalise their relationships, and the latter only had one. Second, this opt-in approach has - rather predictably - failed to resolve the legal (and social) issues faced by all cohabiting couples, many of whom, for whatever reason, do not formalise their relationships. ${ }^{24}$ Therefore, the need to recognise informal cohabitation relationships continued. ${ }^{25}$

As regards the substance of the regimes which (also) created an alternative to marriage, one would be forgiven for automatically assuming that 'alternative' would also imply different legal rules from marriage. Indeed, for many of the jurisdictions following this approach this was the case. ${ }^{26}$ However, this of course enforced the hierarchy and inequality, as same sex couples continued to be denied access to the same rights and duties as opposite sex couples, quickly leading to calls to end this discrimination and, in many cases (but not all - an example is the case of Greece), ${ }^{27}$ ultimately opening up marriage to same sex couples (on which see section 3 of this chapter). However, in the Netherlands and New Zealand, the schemes introduced in substance were almost identical to marriage, ${ }^{28}$ creating an alternative to marriage (almost) in name only. ${ }^{29}$ While there was little between the regimes in substance, the fact that

and by Kathleen Kiernan, 'The Rise of Cohabiting and Childbearing outside Marriage in Western Europe' (2001) 15 International Journal of Law, Policy and the Family 1; Michaela Kreyenfeld and Dirk Konietzka, 'Nichteheliche Lebensgemeinschaften - Demographische Trends und gesellschaftliche Strukturen' in Jens M Scherpe and Nadjma Yassari (eds), Die Rechtsstellung nichtehelicher Lebensgemeinschaften - The Legal Status of Cohabitants (Mohr Siebeck 2005) 45; as well as The Law Commission, Cohabitation, 'The Financial Consequences of Relationship Breakdown' (Consultation Paper No 179, 2006) www.lawcom.gov.uk/?s=cohabitation accessed 11 October 2018, 27.

24 On the reasons see for example Barlow et al above, $\mathrm{n} 23$.

25 On this see Joanna Miles, above n 9; Jens M Scherpe, 'Rechtsvergleichende Gesamtwürdigung und Empfehlungen zur Rechtsstellung nichtehelicher Lebensgemeinschaften' in Jens M Scherpe and Nadjma Yassari, above n 9, 571-605; Jens M Scherpe, 'The Legal Status of Cohabitants - Requirements for Legal Recognition' in Katharina Boele-Woelki (ed.), Common Core and Better Law in European Family Law (Intersentia 2005) 283-94; Jens M Scherpe, 'Protection of Partners of Informal Long-Term Relationships' (2005) 7 International Law FORUM du droit international 207-13, reprinted in Ann Laquer Estin (ed.), International Family Law, Volume I (Edward Elgar 2016) 371-7. See in particular the evidence presented by Anne Barlow, Simon Duncan, Grace James and Alison Park, Cohabitation, Marriage and the Law, Social Change and Legal Reform in the 21st Century (Hart Publishing 2005), esp 49. Anecdotal evidence from France suggests that registration schemes are mainly popular with the (more or less affluent) educated middle classes and that unmarried couples with greater financial needs and lower educational qualifications are less likely to avail themselves of the opportunities that such regimes offer. On France see Laurence Francoz-Terminal, 'Registered Partnerships in France' in Jens M Scherpe and Andy Hayward (eds), The Future of Registered Partnerships - Family Recognition beyond Marriage? (Intersentia 2017) 153.

26 For example in Belgium, France and Greece, on which see the contributions by Geoffrey Willems, Laurence Francoz-Terminal and Dafni Lima in Jens M Scherpe and Andy Hayward (eds), The Future of Registered Partnerships - Family Recognition Beyond Marriage? (Intersentia 2017) 381, 153 and $301 \mathrm{ff}$. 27 Cf Lima, ibid.

${ }_{28}$ For the differences see Ian Sumner, 'Registered Partnerships in the Netherlands' and Margaret Briggs, 'Registered Partnerships in New Zealand', both in Jens M Scherpe and Andy Hayward (eds), The Future of Registered Partnerships - Family Recognition beyond Marriage? (Intersentia 2017) 121 and 439.

29 For a discussion of the need for such an alternative to marriage see for example Andy Hayward, 'The Future of Registered Partnerships in England and Wales' in Jens M Scherpe and Andy Hayward 
opposite sex couples had more choices than same sex couples and the denial of access to the highly symbolic institution of marriage likewise led to calls for reform, which similarly led to the opening up of marriage to same sex couples (on which see below). ${ }^{30}$

\section{THE OPENING UP OF MARRIAGE TO SAME SEX COUPLES AND ITS IMPACT ON REGISTERED PARTNERSHIP SCHEMES}

As just mentioned, same sex couples, both in jurisdictions where there was a 'functional equivalent' and in jurisdictions where there was an 'alternative', continued to campaign and litigate for same sex marriage. ${ }^{31}$ In many jurisdictions these efforts succeeded, and marriage indeed was opened up to same sex couples. In Europe, this was generally achieved through parliamentary reform, although in Ireland this was preceded by a referendum. Austria is the only European jurisdiction where the opening up of marriage was the result of litigation/ judicial decision: ${ }^{32}$ the Austrian Constitutional Court ruled that the 'functional equivalent' approach was unconstitutional, and therefore held not only that marriage had to be open to same sex couples but also that consequentially the option of registered partnership must be available to opposite sex couples. ${ }^{33}$

Other European jurisdictions, such as Portugal and Spain (federal law), introduced same sex marriages without having previously had some form of registered partnership. But for those who did already have registered partnership laws, the advent of same sex marriage required a decision on what to do with these existing legal regimes.

(eds), The Future of Registered Partnerships - Family Recognition beyond Marriage? (Intersentia 2017) 527.

30 For a comparative analysis of the developments see Jens M Scherpe, 'The Past, Present and Future of Registered Partnerships' in Jens M Scherpe and A Hayward (eds), The Future of Registered Partnerships - Family Recognition beyond Marriage? (Intersentia 2017) 561.

31 See e.g. the case of Wilkinson v Kitzinger [2006] EWHC 2022 (Fam). For a comparative overview see Jens M Scherpe, ibid.

32 Outside of Europe it is much more common for this to be the result of litigation, for example in South Africa (Constitutional Court, Minister of Home Affairs and Another v Fourie and Another; Lesbian and Gay Equality Project and Others v Minister of Home Affairs and Others, [2005] ZACC 19), the United States (Supreme Court in Obergefell v Hodges 576 U.S. (2015), preceded by several state constitutional court decisions); Brazil (STF, ADPF/132 and ADI 4277, Justice Rapporteur Ayres Britto, j. 05/05/2011; STJ, REsp 1.183.378 - RS, $4^{\text {a }}$ T., Justice Rapporteur Luis Felipe Salomão, j. 25/10/2011; National Council of Justice Resolution 175/2013), Columbia (Corte Constitucional, Sala Plena, 28 April 2016, SU-214/16), Taiwan (Judicial Yuan (JY) Interpretation No. 748 of 24 May 2017); Inter-American Court of Human Rights Inter-American Court of Human Rights, Advisory Opinion (Opinión Consultiva, OC) 24/17 of 24 November 2017, requested by the Republic of Costa Rica, Opinión consultiva sobre identidad de género, y no discriminación a parejas del mismo sexo, available at www.corteidh.or.cr/docs/ opiniones/seriea_24_esp.pdf (last accessed 24 April2018).

33 Verfassungsgerichtshof 4.12.2017 (G 258-129/2017-9), www.vfgh.gv.at/downloads/VfGH _Entscheidung_G_258-2017_ua_Ehe_gleichgeschlechtl_Paare.pdf (last accessed 30 April 2018). 


\subsection{Impact on 'Functional Equivalent' Jurisdictions - Abolition, Retention and Confusion}

In almost all jurisdictions in which registered partnerships had been introduced as a (more or less) functional equivalent of marriage, the registered partnership schemes were abolished (in the sense that entering into such partnerships was no longer possible).$^{34}$ Essentially, it was felt that when everybody had access to marriage, the other scheme was no longer necessary, as it had really been introduced in order to avoid opening up marriage in the first place. ${ }^{35}$ Where this happened, it meant that all couples still had one possibility to formalise their relationship, except that now this was marriage.

However, some jurisdictions which had originally introduced registered partnership as a functional equivalent took a different path. In Austria this happened as a result of the abovementioned Constitutional Court decision, which opened up not only marriage but also registered partnership to all couples, creating a system in which all couples could now choose between the two regimes. ${ }^{36}$ The same was achieved by legislation for the Isle of Man, which at the time of writing is the only jurisdiction of the British Isles where this is possible, although on 2 October 2018 then Prime Minister Theresa May announced a similar move for England and Wales, and indeed the first civil partnerships between couples of the opposite sex now will become possible on 31 December 2019.37

But the most notable jurisdictions, at least currently, in international comparison are England and Wales and Scotland. ${ }^{38}$ When marriage was opened up to same sex couples in

34 For example in Denmark, Norway, Sweden and Iceland (on which see the contributions by Ingrid Lund-Andersen, Thomas Eeg, Margareta Brattström and Caroline Sörgjerd, and David Thór Bjørgvinsson, in Jens M Scherpe and A Hayward (eds), The Future of Registered Partnerships - Family Recognition Beyond Marriage? (Intersentia 2017), 19, 53, 71, 101) but also in Germany after the Gesetz zur Einführung des Rechts auf Eheschließung für Personen gleichen Geschlechts entered into force on 1 October 2017, and in Ireland after the Marriage Act 2015 entered into force on 16 November 2015 (in the development in Ireland see Brian Tobin, 'Registered Partnerships in the Republic of Ireland' in Jens M Scherpe and Andy Hayward (eds), The Future of Registered Partnerships - Family Recognition Beyond Marriage? (Intersentia 2017), 277.

35 Or, as it has been put, as a 'consolation prize' for not opening up marriage to same sex couples: cf the reasoning by the complainants in Wilkinson v Kitzinger [2006] EWHC 2022, [5]-[6].

${ }_{36}$ Above, n. 33. One of the reasons for this was that it was not open to the Court to abolish registered partnership, and in order to avoid discrimination the approach taken was the only one feasible without parliamentary intervention. Also, there are some differences between marriage and registered partnership in Austria, particularly with regard to dissolution, but also the absence of the policy enshrined in $\S 44$ ABGB, according to which the two persons getting married promise each other to live together, have children and raise them together, and so on.

37 For the Isle of Man see www.gov.im/categories/births-deaths-and-marriages/marriage-and-civil -partnership/ (last accessed 11 October 2018); for the Prime Minister's announcement see www.bbc.co .uk/news/uk-politics-45714032 (last accessed 11 October 2018).

38 Although admittedly the same applies to Jersey and some British Overseas Territories. Of the latter, Bermuda had same sex marriage for a period of time after the Supreme Court ruled accordingly on 5 May 2017, but it was abolished and replaced by 'domestic partnerships' through the Domestic Partnerships Act 2018, making Bermuda the only jurisdiction which ever did so (as the Californian 'Proposition 8' ultimately failed to become law after the US Supreme Court decision in Hollingsworth $v$ Perry 133 S. Ct. 2652 (2013)). 
these jurisdictions, ${ }^{39}$ the registered partnership regimes were left untouched, ${ }^{40}$ resulting in a bizarre situation in which same sex couples had two options to formalise their relationship, whereas opposite sex couples had only one. This made these jurisdictions the only major ones in which opposite sex couples were discriminated against. Remarkably, the English government expressly maintained that since there was no differential treatment in substance, there was no need for any legislative action. ${ }^{41}$ But it should be obvious to anyone that two options to formalise one's relationship are more than one, irrespective of the legal consequences that such formalisation brings with it. The Court of Appeal found the status quo to be discriminatory in principle, ${ }^{42}$ but curiously, the majority in the case allowed the government time to remedy this without a declaration of incompatibility under section 4 Human Rights Act, which would have seemed the obvious way forward, ${ }^{43}$ and indeed is what was decided on appeal by the Supreme Court. ${ }^{44}$ Therefore reforms were inevitable, and as mentioned above, England and Wales now will open up civil partnership to opposite sex couples as well at the end of 2019 .

In any event, before the legal proceedings, both jurisdictions undertook a review of the law of civil partnership, neither of which have yet resulted in any reforms of the law. ${ }^{45}$ While the Scottish review did not make any recommendations but merely pointed out the options, the English review, conducted by the Department for Culture, Media and Sport before the abovementioned Court of Appeal decision was handed down, concluded that the status quo was fine. What was striking about the way the English review was conducted was not only the absence of any discussion of issues of human rights and/or discrimination, ${ }^{46}$ but also the almost complete lack of engagement with crucial issues. The parochial attitude of the English review is best captured by the statement that '[a]lmost no respondents mentioned benefits other than in

39 Marriage (Same Sex Couples) Act 2013, and Marriage and Civil Partnership (Scotland) Act 2014.

40 The actual term used in those jurisdictions is 'civil partnerships'.

${ }^{41}$ Cf the government's arguments in Steinfeld and Keidan v Secretary of State for Education [2016] EWHC 128 and [2017] EWCA Civ 81. For a detailed account of this see Andy Hayward, 'Registered Partnerships in England and Wales' in Jens M Scherpe and Andy Hayward (eds), The Future of Registered Partnerships - Family Recognition beyond Marriage? (Intersentia 2017) 187.

${ }_{42}$ After the High Court, taking a somewhat bizarre approach to the matter, failed to do so: [2016] EWHC 128 (Admin). For a comment on this decision see Claire Fenton-Glynn, 'Opposite-Sex Civil Partnership and the Ambit of Art. 8' (2016) 46(4) Family Law 431-3.

43 Steinfeld and Keidan $v$ Secretary of State for Education [2017] EWCA Civ 81.

44 Steinfeld and Keidan v Secretary of State for Education [2018] UKSC 32; for an extensive case comment see Jens M. Scherpe, 'Family Law, Ideology and the Recognition of Relationships: R (Steinfeld and Keidan) v Secretary of State for International Development' in Daniel Clarry (ed.), The UK Supreme Court Yearbook, Volume 9: 2017-2018 Legal Year (Appellate Press, 2019) pp. 150-173.

45 Department for Culture, Media \& Sport, 'Civil Partnership Review (England and Wales): A Consultation' (January 2014) www.gov.uk/government/consultations/consultation-on-the-future-of -civil-partnership-in-england-and-wales (accessed 11 October 2018); The Scottish Government, Review of Civil Partnership: A Consultation by the Scottish Government' (September 2015) https://consult.gov .scot/family-law/review-of-civil-partnership/ (accessed 11 October 2018).

46 There was merely one reference to the ECHR: a sentence stating that an application to the European Court of Human Rights concerning civil partnership had been declared inadmissible, without any reference or discussion. But it can be assumed that the report refers to Ferguson et al. $v$ United Kingdom, File number 8254-11, 2 February 2011. However, that application had a different/wider scope than the issue in question in the consultation, and the decision was merely one of inadmissibility and not substance; thus, this should in no way preclude the need for a discussion of the matter. 
terms of advancing equality if civil partnerships were opened up to opposite sex couples' ${ }^{47}$ As I have said elsewhere, ${ }^{48}$ the dismissive tone of this statement and the apparent lack of commitment to the principles of equality and nondiscrimination is worrying in itself. ${ }^{49}$ But considering that it was the very same government that opened up marriage to same sex couples explicitly for equality reasons, the government's stance simply was inconsistent and, frankly, absurd.

It seems unthinkable that any English government or governmental office would have argued similarly had the issue been one of differential treatment/discrimination because of religion or race. Consider the following example: $:^{50}$ between cities $\mathrm{A}$ and $\mathrm{B}$ there are bus services. Some buses are red, others are blue. Otherwise they are the exact same models and take the exact same time to get from A to B. However, the law says that white people are only allowed to take the red bus, whereas all other people are allowed to take both blue and red buses. Mrs X - who is white, objects to this distinction and also does not like red buses for ideological reasons - complains that she is being discriminated against. Surely here nobody would argue that there is no differential treatment, simply because Mrs X could take a red bus if she wanted to? Hence - at the very least - the people behind the laws would need to justify this differential treatment (which would be impossible, one hopes).

Obviously, marriage is the red bus in this example. Why does the government feel that, in the context of gender, sex, and sexual orientation, it can seriously argue that there is no differential treatment or discrimination - which it surely would never have done had the issue been one of religion or race? One may be forgiven for thinking that apparently issues of gender, sex and sexual orientation seem to be given less consideration than others. This is disconcerting, particularly since the European Court of Human Rights has rightly and consistently held that 'particularly serious reasons' are required to justify differential treatment based on sexual orientation. ${ }^{51}$

The lack of real engagement can also be seen in other statements by the government, for example that civil partnership was an 'established mechanism' 52 for recognising same sex relationships and therefore should remain as is, and that they had been 'unable to identify a need' for opening up civil partnership to opposite sex couples. ${ }^{53}$ As Joanna Miles has rightly

47 Department for Culture, Media \& Sport, 'Civil Partnership Review (England and Wales): Report on Conclusions' (June 2014) www.gov.uk/government/consultations/consultation-on-the-future-of-civil -partnership-in-england-and-wales (accessed 11 October 2018), para 2.30.

48 Jens M Scherpe above, n. 30.

49 As rightly pointed out by Joanna Miles in Sonia Harris-Short, Joanna Miles and Rob George, Family Law (Oxford University Press, 3rd edition 2015) at 2.6.1.

${ }_{50}$ Example taken from Jens M Scherpe, 'Comment on ECtHR 26.10.2017 (Ratzenböck and Seydl v. Austria)', [2017] FamRZ 2031.

51 Established in Dudgeon v United Kingdom (22 October 1981), (1982) 4 EHRR 149. Indeed, the position of the Court has moved further, and, after the decisions in Schalk and Kopf v Austria [2010] ECHR 995 (on which see n. 4), Vallianatos and others $v$ Greece [2013] ECHR 1110 and particularly Oliari and others $v$ Italy [2015] ECHR 716, arguably requires establishing a legal framework for same sex couples. On this see for example Helen Fenwick, 'An ECHR Right to Access to Registered Partnerships?' in Jens M Scherpe and A Hayward (eds), The Future of Registered Partnerships - Family Recognition beyond Marriage? (Intersentia 2017) 471.

${ }^{52}$ Government Equalities Office, 'Equal Civil Marriage: A Consultation’ (March 2012) www.gov .uk/government/uploads/system/uploads/attachment_data/file/133258/consultation-document_1_.pdf accessed 11 October 2018), para 2.19.

53 Ibid, para 2.20 . 
pointed out, it 'seems particularly odd to suggest that civil partnership should be kept as it is as a means of recognizing same-sex relationships when marriage - hitherto an extremely well-established mechanism for recognizing opposite-sex relationships - has just been opened up to same-sex couples'. ${ }^{54}$

Apart from the intellectual inconsistency, it is worrying that the government apparently ignored not only its own findings, namely that 20 per cent of unmarried heterosexual respondents to the civil partnership consultation said that they would rather enter into a civil partnership than marry, ${ }^{55}$ but also publicly available empirical research which established very clearly that some couples, for ideological reasons, prefer civil partnership to marriage because of the 'patriarchal and quasi-religious tenets embedded even within civil marriage ${ }^{56}$ - which, of course, also are among the reasons for the litigation in Steinfeld and Keidan. ${ }^{57}$

Ultimately the government concluded that, given the 'lack of consensus' on this issue, there is no need for any legal change. ${ }^{58}$ Again, this is deeply alarming, and such a statement surely would be unthinkable in other contexts such as discrimination because of religion or race. Not only did the government have absolutely no difficulty in opening up marriage despite there clearly being no consensus on the matter, ${ }^{59}$ but eliminating discrimination cannot and must not be a question of 'consensus', as otherwise a majority could always prevent any such measures. The whole point of antidiscrimination measures and legislation is to protect minorities from being discriminated against, irrespective of whether the majority agrees or not. Admittedly, in the given context, opposite sex couples are not a minority (although those couples that would prefer a civil partnership to a marriage probably are), but in this context that is irrelevant. Protection from discrimination can never require a 'social consensus', but is a question of law and, particularly, human rights. No government would seriously rely on 'lack of consensus' when it came to discrimination because of religion or race and potential human rights violations, and the same must of course be the case when issues of gender, sex or sexual orientation are concerned. But the abovementioned decision of the Supreme Court forced Parliament's hand, leading to the abovementioned reform.

\subsection{No Real Impact on 'Alternative to Marriage' Jurisdictions}

By comparison to those jurisdictions looked at in the previous section, the opening up of marriage to same sex couples, somewhat predictably, had little or no impact on registered partnership schemes in jurisdictions where these schemes had been introduced for both same and opposite sex couples. Here the existing schemes, in addition to being the first way for same sex couples to formalise their relationship, fulfilled the function of being an alternative

\footnotetext{
$54 \quad$ Joanna Miles above, n. 49.

55 Department for Culture, Media \& Sport above, n. 47, paras 2.18-2.19.

56 Anne Barlow and Janet Smithson, 'Legal Assumptions, Cohabitants' Talk and the Rocky Road to Reform' (2010) 22(3) Child and Family Law Quarterly 328-50, esp 336.

57 Above, n. $41 \mathrm{ff}$.

58 Department for Culture, Media \& Sport above, n. 47, para 3.10.

59 The consultation on same sex marriage (Government Equalities Office above, n. 52) had the largest number of responses of any consultation process in the history of the United Kingdom, with some 228,000 individual responses (more than half of which supported the proposal to allow same-sex couples to marry in a civil ceremony) and 19 collective petitions against the proposal (between them half a million signatures).
} 
to marriage for opposite sex couples. Not only did the political reasons for introducing such a scheme (whether one agrees with them or not) still apply, as introducing same sex marriage did not affect them, but many opposite sex couples indeed had consciously chosen to enter into a registered partnership instead of marriage, and it therefore appeared to be an attractive alternative to some. ${ }^{60}$ Abolishing the scheme therefore would have meant removing that option for the future (and potentially even disenfranchising those who had already chosen it), and would also create a situation where opposite sex couples had been given a choice for at least some period of time, whereas same sex couples would never have had that choice. This would have required significant justification - and in effect an admission that the introduction of the registered partnership in that form had been a mistake. Therefore, unsurprisingly, all jurisdictions in that position retained their registered partnership schemes.

\subsection{The Absurdity of Focusing on Legal Gender - Moving beyond the Binary}

The opening up of marriage in some jurisdictions also brought with it a renewed focus on legal gender - somewhat contrary to the intentions of the legislatures, considering that the motivation for these reforms was that it should not matter which legal gender the persons entering into the marriage have. But, rather ironically, in their eagerness to bring about this modernisation of their family laws, several jurisdictions - such as Denmark, ${ }^{61}$ England, ${ }^{62}$ and Germany ${ }^{63}$ felt it necessary to expressly refer to the legal gender/sex of the persons concerned, with the respective statutes stating (with variations) that marriages can now be entered into by persons of the same or the opposite legal gender/sex. ${ }^{64}$ This, at least in theory, obliges the registrar/ celebrant to check which of the two possibilities applies to the marriage about to be entered into, and thus to check legal gender/sex, and potentially allows for a 'categorisation' and even separation/different treatment of same sex and opposite sex marriages. Given that the whole point was that marriage should be open to anyone, that it should be one and the same institution, and that legal gender/sex should no longer matter, this is counterproductive. It would have been much easier, and in the spirit of the reforms, to change the law to 'two persons can enter' - as, for example, Malta has done ${ }^{65}$ - thus truly degendering marriage, as was (at least officially) the legislative intention in the first place.

Developments in the law of recognition of preferred gender and the recognition of legal genders other than male or female reinforce the point just made. As regards the former, in an

${ }^{60}$ On the popularity of such schemes for example in France and the Netherlands see Ian Sumner, above n. 28, and Laurence Francoz Terminal, above n. 25. By comparison, in New Zealand the takeup rates were much lower, which can be explained by the existence of the extensive regime available for cohabitants/de facto couples: cf Margaret Briggs, above, n. 28.

${ }^{61} \S 1$ Lov om ægteskabs indgåelse og opløsning.

62 Section 1(1) Marriage (Same Sex Couples) Act 2013. But at least the reference to the legal gender/ sex of the parties was deleted (formerly Section 11(c) Matrimonial Causes Act 1973).

${ }_{63} \S 1353$ Abs. 1 Bürgerliches Gesetzbuch (BGB, German Civil Code).

${ }^{64}$ On this see also Jens M Scherpe, 'How Not to Reform Family Law - An Example from England' in Birgit Ilkær-Jordan, Marianne Holdgaard and Kirsten Reimers-Lund (eds), Danmarks Familieadvokat: Festskrift til Jørgen U. Grønborg (eget forlag 2016) 143-58.

${ }_{65}$ Marriage Act and other Laws (Amendment) Act 2017. 
increasing number of jurisdictions (for example Argentina, ${ }^{66}$ Denmark, ${ }^{67}$ Malta, ${ }^{68}$ Portugal, ${ }^{69}$ Ireland, ${ }^{70}$ Taiwan $^{71}$ ), the legal gender of a person is now essentially their choice, as it can be changed by self-determination. ${ }^{72}$ When legal gender effectively becomes a choice, then legal gender requirements for relationship recognition become rather meaningless.

Moreover, with regard to legal genders other than male or female, some jurisdictions currently allow persons to leave open their legal gender entry in the birth register. An example is Germany, ${ }^{73}$ where this has been allowed since 2013 according to $\S 22$ para. 3 Personenstandsgesetz (Civil Registry Act) ${ }^{74}$ if the person cannot be assigned to the female or male gender. This applies if they were born with sex characteristics (such as chromosomes, genitals and/or hormonal structure) that do not belong strictly to male or female categories, or that belong to both at the same time, often referred to as 'intersex' ${ }^{75}$ However, it must be pointed out that this approach (while undoubtedly well intended) is very problematic, as it

${ }^{66}$ Laura María Giosa, María Victoria Schiro and Peter Dunne, 'The Legal Status of Transgender and Transsexual Persons in Argentina' in Jens M Scherpe (ed.), The Legal Status of Transsexual and Transgender Persons (Intersentia 2015) 571.

${ }_{67}$ Natalie Videbaek Munkholm, 'The Legal Status of Transsexual and Transgender Persons in Denmark' in Jens M Scherpe (ed.), The Legal Status of Transsexual and Transgender Persons (Intersentia 2015) 165.

${ }_{68}$ Tanya Ní Mhuirthile, 'The Legal Status of Intersex Persons in Malta' in Jens M Scherpe, Anatol Dutta and Tobias Helms (eds), The Legal Status of Intersex Persons (Intersentia 2018) 357-67.

69 The Act was passed on 13 April 2018. On the Parliamentary proceedings see www.parlamento.pt/ ActividadeParlamentar/Paginas/DetalheIniciativa.aspx?BID=40691 accessed 11 October 2018.

70 Gender Recognition Act 2015.

71 Chih-hsing Ho, 'The Legal Status of Transsexual and Transgender Persons in Taiwan' in Jens M Scherpe (ed.), The Legal Status of Transsexual and Transgender Persons (Intersentia 2015) 425.

${ }^{72}$ For a comparative study see Jens M Scherpe (ed.), The Legal Status of Transsexual and Transgender Persons (Intersentia Cambridge 2015). It is worth noting that in a recent Advisory Opinion the Inter-American Court of Human Rights held that recognition of preferred gender should not require certificates which are unreasonable or imply pathology, nor require accrediting surgical or hormonal procedures: cf Inter-American Court of Human Rights, Advisory Opinion (Opinión Consultiva, OC) $24 / 17$ of 24 November 2017, requested by the Republic of Costa Rica, Opinión consultiva sobre identidad de género, y no discriminación a parejas del mismo sexo, www.corteidh.or.cr/docs/opiniones/seriea 24_esp.pdf (accessed 28 April 2018). Shortly before this, the European Court of Human Rights held in $\bar{A} P$, Garçon \& Nicot v France [2017] ECHR 338 that making recognition of gender identity contingent on undergoing surgery that may lead to sterility is a violation of the ECHR.

73 Other jurisdictions include Nepal and India, on which see Smita Shah, 'The Legal Status of Intersex Persons in India and the Decision of the Supreme Court of India' in Jens M Scherpe, Anatol Dutta and Tobias Helms (eds), The Legal Status of Intersex Persons (Intersentia 2018) 281-92.

${ }_{74}$ On this see Tobias Helms, 'Personenstandsrechtliche und familienrechtliche Aspekte der Intersexualität vor dem Hintergrund des neuen $\S 22 \mathrm{Abs} .3$ PStG' in Isabell Götz et al. (eds), Festschrift für Gerd Brudermüller zum 65. Geburtstag (Beck 2014) 301; Tobias Helms, Brauchen wir ein Drittes Geschlecht? Reformbedarf im deutschen (Familien-)Recht nach Einführung des \&22 Abs. 3 PStG (Walter de Gruyter 2015); Wolf Sieberichs, 'Das unbestimmte Geschlecht' [2013] FamRZ 1180.

75 Definition by Dan Christian Ghattas, 'Standing Up for the Human Rights of Intersex People - How Can You Help' (2015), p.9 https://oiigermany.org/toolkit-standing-up-human-rights-intersex -people/ (accessed 11 October 2018). In the biomedical debates/literature, the term 'differences in sex development' appears to dominate. On this term and why it is problematic see Ieuan Hughes, 'Biology of Fetal Sex Development' in Jens M Scherpe, Anatol Dutta and Tobias Helms (eds), The Legal Status of Intersex Persons (Intersentia 2018) 25-44; and Jens M Scherpe and Jameson Garland, 'Ethical and Legal Aspects of DSD/Intersex' in Ilpo Huhtaniemi et al (eds), Encyclopedia of Endocrine Diseases (Elsevier, 2nd edition 2018) 581. 
singles out and potentially stigmatises intersex persons, and at the same time increases the danger of medically unnecessary and in many cases deeply harmful surgery to 'normalise' children born with intersex conditions. ${ }^{76}$ Furthermore, jurisdictions are beginning to move beyond the binary legal gender system; indeed, Germany was required to by the end of 2018 because of a decision of the German Constitutional Court. ${ }^{77}$ In that decision, the Court held that the abovementioned $\S 22$ Abs.3 Personenstandsgesetz was in violation of the German Basic Law (the German Constitution), as it merely allowed for a nonregistration rather than a positive recognition of a gender other than male or female. Interestingly, the Court also suggested that not registering the gender of (all) persons would also be a viable option. ${ }^{78}$ The Court gave Parliament until the end of 2018 to put legislation in place to remedy this situation, meaning that Germany became the first jurisdiction in the world to introduce a nonbinary legal gender system by statute by creating a third gender option (rather than a third gender) of 'diverse'. Very problematically, this option was not made available to all persons who do not identify as male or female/non-binary but only to intersex persons. Thus further litigation on this issue can be expected. But whatever one's view of this reform is, it was the end of the binary legal gender system in Germany. Shortly after, the Austrian Constitutional Court reached a similar conclusion, but maintained that the recognition of nonbinary genders could be achieved by statutory interpretation. ${ }^{79}$ This, inevitably, will have to lead to a review not only of relationship recognition laws, but of all gendered legal provisions. While this may only affect Germany and Austria in the first instance, the effects will have to be dealt with by other jurisdictions with gendered legal provisions when these provisions are to be applied to a person with a (positive) legal gender other than female or male..$^{80}$

There can be no doubt that all persons have the right to marry and form meaningful (legal) relationships, including those who do not have a legal gender of male or female, or indeed any legal gender at all. But a legal gender requirement of marrying someone of 'the same or the opposite sex' may, at least in theory, create an insurmountable barrier to marriage/relationship recognition for those outside of the legal gender binary. That said, in practice it is likely that the wording of the marriage and relationship recognition requirements will indeed be interpreted to mean 'two persons' and/or at least include persons without a binary legal gender ${ }^{81}$

76 On which see Jameson Garland and Milton Diamond, 'Evidence-Based Reviews of Medical Interventions relative to the Gender Status of Children with Intersex Conditions and Differences in Sex Development' and Morgan Carpenter, "The "Normalisation" of Intersex Bodies and "Othering" of Intersex Identities', both in Jens M Scherpe, Anatol Dutta and Tobias Helms (eds), The Legal Status of Intersex Persons (Intersentia 2018) 81-101 and 445-514; see also Jens M. Scherpe/Jameson Garland, 'Ethical and Legal Aspects of DSD/Intersex' in Ilpo Huhtaniemi (ed.), Encyclopedia of Endocrine Diseases (Academic Press/Elsevier, 2nd ed. 2018) 581-590.

77 BVerfG 1 BvR 2019/16 (10.10.2017), Zeitschrift für das gesamte Familienrecht (FamRZ) 2017, 2046. Cf the English language press release no 95/2017 of 8.11 .2017 , available at www .bundesverfassungsgericht.de/SharedDocs/Pressemitteilungen/EN/2017/bvg17-095.html accessed 11 October 2018.

78 Ibid.

79 Verfassungsgerichtshof 29.6.2018, G 77/2018-19, with English press release available at www .vfgh.gv.at/medien/Civil_register_-_Intersex_persons.en.php (accessed 11 October 2018).

${ }_{80}$ Cf also Jens M S cherpe, 'Mehr Freiheit wagen im Familienrecht: Entgeschlechtlichung des Rechts' in Anatol Dutta and Christian Heinze (eds), Mehr Freiheit wagen (Mohr Siebeck 2018).

${ }_{81}$ As suggested also by Dieter Schwab, 'Eheschließung für Personen gleichen Geschlechts' [2017] FamRZ 1285-9. See also Jens M Scherpe above, n.82. 
- though that does not change, but rather reinforces, the point made above: that the statutory wording where relationship recognition was intended to be independent of legal gender really should have been 'two persons' in the first place.

\section{BEYOND CONJUGALITY, BEYOND COUPLEDOM?}

Apart from a focus on gender, relationship recognition law in most jurisdictions is solely focused on conjugal couples, although there are exceptions. For example, Belgium permits registered partnerships between any two persons, ${ }^{82}$ and New South Wales and Tasmania recognise 'caring relationships'. ${ }^{83}$ Norwegian law at least recognises some form of household community, but with very limited effects. ${ }^{84}$ While of course it needs to be acknowledged that the nature and the legal needs of such relationships are likely to be different from conjugal couple relationships, this does not mean that there is no need for their recognition, be it through a registration scheme or a regime based on informal/de facto relationships or only in some areas of law (obvious areas here are tax law, succession law and social welfare and social security law). Hence in the future we will probably see more schemes like those in Belgium, New South Wales and Tasmania. ${ }^{85}$

But not only is there a focus on conjugality; there is also a limitation to two persons. ${ }^{86}$ Certainly, once one moves beyond conjugality and into carer and other relationships, there is little justification to limit those schemes/recognition to two persons. An obvious example is an elderly parent being cared for by two of their children. If the scheme is only open to two persons, only one of the carers could benefit, which appears somewhat contrary to the legislative intention of supporting caring relationships in general. Furthermore, such relationships probably ought to be recognised in addition to other existing relationships, as the carers may well be in a different kind of relationship with somebody else (including, for example, a marriage), but this should not preclude their care work being supported and recognised by law.

Also, there are persons living in enduring polyamorous relationships (so conjugal relationships), which for many reasons may also want legal recognition of their relationships. Relationship recognition of course originally started with the marriage paradigm and thus in Western societies was limited to two persons, but there seem no obvious reasons why that limitation needs to be upheld. What kind of legal regime may be appropriate for this is of course a very different matter.

82 See Geoffrey Willems, 'Registered Partnerships in Belgium' in Jens M Scherpe and Andy Hayward (eds), The Future of Registered Partnerships - Family Recognition beyond Marriage? (Intersentia 2017) 381-409.

${ }_{83}$ See Stevie Martin, 'Registered Partnerships in Australia' in Jens M Scherpe and Andy Hayward, The Future of Registered Partnerships - Family Recognition beyond Marriage? (Intersentia 2017) 411-38.

${ }_{84}$ Thomas Eeg above, n. 7, and Eva Ryrstedt, 'Legal Status of Cohabitants in Norway' in Jens M Scherpe and Nadjma Yassari (eds), Die Rechtsstellung nichtehelicher Lebensgemeinschaften - The Legal Status of Cohabitants (Mohr Siebeck 2005) 439-54.

85 See also Law Commission of Canada, 'Beyond Conjugality: Recognizing and Supporting Close Personal Adult Relationships' (2001), http://epe.lac-bac.gc.ca/100/200/301/lcc-cdc/beyond_conjugality -e/html/front-e.html (accessed 11 October 2018).

86 Apart from the household community in Norway: see above, n. 84. 


\section{TOWARDS A FUNCTIONAL APPROACH TO RELATIONSHIP RECOGNITION}

In many jurisdictions, relationship recognition law has changed radically, breaking away from the paradigm of 'traditional' marriage in terms of gender, formality requirements and (although so far to a more limited extent) conjugality. The next 'barrier' to relationship recognition to fall is likely to be the limitation to two persons and the exclusivity requirements. Thus, there is a clear trend towards a functional approach to relationship recognition.

That said, it is of course important to note that this is only true for some, usually Western, jurisdictions, and that for many other jurisdictions such changes, particularly with regard to gender, seem unlikely in the foreseeable future. However, modern human rights instruments and continuous and persistent activism will hopefully lead to changes sooner rather than later, allowing people to love and to live their relationships without such restrictions. 